\title{
GCU
}

Glasgow Caledonian

University

University for the Common Good

\section{Inclusive identities: re-imaging the future of the retail brand?}

Boyd, Callum S.; Ritch, Elaine L.; Dodd, Christopher A.; McColl, Julie

Published in:

International Journal of Retail and Distribution Management

DOI:

10.1108/IJRDM-12-2019-0392

Publication date:

2020

Document Version

Author accepted manuscript

Link to publication in ResearchOnline

Citation for published version (Harvard):

Boyd, CS, Ritch, EL, Dodd, CA \& McColl, J 2020, 'Inclusive identities: re-imaging the future of the retail brand?', International Journal of Retail and Distribution Management, vol. 48, no. 12, pp. 1315-1335.

https://doi.org/10.1108//JRDM-12-2019-0392

\section{General rights}

Copyright and moral rights for the publications made accessible in the public portal are retained by the authors and/or other copyright owners and it is a condition of accessing publications that users recognise and abide by the legal requirements associated with these rights.

Take down policy

If you believe that this document breaches copyright please view our takedown policy at https://edshare.gcu.ac.uk/id/eprint/5179 for details of how to contact us. 


\section{PUBLISHING International Journal of Retail \& Distribution Manag}

\section{Inclusive Identities: Re-imaging the future of the retail} brand?

\begin{tabular}{|r|l|}
\hline Journal: & International Journal of Retail \& Distribution Management \\
\hline Manuscript ID & IJRDM-12-2019-0392.R3 \\
\hline Manuscript Type: & Research Paper \\
\hline Keywords: & $\begin{array}{l}\text { Gender, LGBTQIA+, Diversity, Marketing, Retail brand value, social } \\
\text { identity }\end{array}$ \\
\hline
\end{tabular}

SCHOLARONE ${ }^{m}$

Manuscripts 


\title{
Inclusive Identities: Re-imaging the future of the retail brand?
}

\begin{abstract}
Purpose: To examine consumers' perceptions of retail brand representations of gender-oriented and/or sexuality-oriented identities. The authors explore the value of developing more progressive, inclusive brand values to support more effective retail brand communications and imagery.

Design: Photoelicitation, utilising LGBTQIA+/sexuo-gendered imagery from retail brand marketing communications, facilitated discussion within focus groups representing various genders, age generations and sexualities.

Findings: Younger generations indicate a preference for fluid gender and sexuality and endorse retail brands that represent this progressive understanding. Gender and age moderate preferences for representative imagery, with older males more resistant to sexuo-gendered messages and females of all ages more accepting.
\end{abstract}

Research limitations: The research is limited in generalisability, geography and demographics. The focussed approach did, however, enable collection of rich, insightful data to underpin evaluations of communicative brand values.

Practical implications: The inclusion of diverse and fluid sexuo-gendered identities within the brand values of retailers would enable effective targeting of consumers across a range of more traditional cohorts.

Social implications: The evolving ideology towards inclusiveness, identified within the generational cohorts, demonstrates social change through progressive acceptance of more fluid gendered and sexual identities.

Originality/value: The research adopts a novel approach to examining diverse, sexuo-gendered imagery within gendered and generational cohorts, offering qualitative examples of a progressive social ideology.

Paper Type: Research paper

Keywords: retail brands; gender; social identity; LGBTQIA+; gender/sexual fluidity; feminism

\section{Introduction}

\section{Identity, sexuo-gendered diversity and retail brand values}

Within mainstream society, identity constructs primarily represent dualistic heterosexual gendered identities (Ivory, 2019; Gong, 2019; Nölke, 2018; Schofield and Schmidt, 2005), which prescribe stereotypical masculine/feminine appearances and assumed roles (Schroeder and Zwick, 2004) that include, for instance, gendered fashion, make-up, body grooming, body-shapes and life-style choices. Extant research has long argued that marketers shape notions of gendered identities (McCraken, 1990). Although this influence has perhaps decreased over the last fifty years, it persists, especially for females (Grau and Zotos, 2016). Similarly, discourse around sexual identities is diffusing into mainstream communities (Nölke, 2018), with Lesbian, Gay and Bisexual (LGB) identities becoming more prominent in mainstream society (Sha et al., 2007; Pounders and Mabry-Flynn, 2016). These 'sexuo-gendered' identities (covering multiple sexual and gender representations), where gender and sexuality fuse within a more inclusive and progressive understanding, may offer a useful base from which to explore relationships between people and retail brands. 
This progressive acceptance of primarily sexuality-driven identities has not been replicated, however, for other sexuo-gendered communities (e.g. transgender), for whom there appears to be a continued taboo (Testa et al., 2012). Over the last decade, what was termed the gay community has expanded beyond LGB to LGBTQIA+, to those questioning $(Q)$ their gender and sexuality, transsexuals $(T)$, intersex (I) and asexual (A) with the plus (+) illustrating the multiple other sexual and gender identities (see Gold, 2019 for a full explanation on the terminology covering the gender and sexuality spectrum). LGBTQIA+ terminology is not a Westernised concept, however, studies in Eastern European and Asian markets tend to be sociological, based around human rights and erotic identities (Berry et al., 2003). Yet, where sexuo-gendered identities are acknowledged, this seems often to be conditional upon a stereotypical, narrow characterisation of identities (Grau and Zotoz, 2016), potentially to avoid anticipated offence taken by mainstream audiences (Hester and Gibson, 2007). Moreover, retail marketing has focused on presenting idealistic lifestyles that mimic heteronormality which do not threaten the dominant socially acceptable gender-constructs of most societies; examples include sexuo-gendered characters that are aesthetically pleasing and fulfil stereotypical characteristics, such as fashion-conscious gay men (Dotson et al., 2009), middle-class white gay couples and nuclear families (Nölke, 2018).

Mainstream representation of sexuo-gendered identities may encourage acceptance of gender and sexuality fluidity (Grau and Zotos, 2016). This appears to be contained, however, within normative boundaries that continue to restrict diverse identity construction and fluidity. As sexuo-gendered conceptualisations fragment (Schofield and Schmidt, 2005) (for instance, to include gender-neutral and non-binary identities, amongst others), retail marketers are faced with the usual dilemma of either retaining a narrower homogenised approach or embracing a growing multiplicity of commodification opportunities (e.g. via hyper-segmentation strategies) (Nölke, 2018).

This value of sexuo-gendered identities within retail marketing has received relatively little academic or practitioner attention (Ivory, 2019; McIntyre, 2018; Dotson et al., 2009). Grau and Zotos (2016) called for more research on the consequences of how gender is represented in marketing. Most sexuogendered research emerges from the USA and does not include perceptions of how diverse identities can inform retail brand values. Academic research exploring mainstream perceptions of transgender identities emerged in the mid-1990s, however, it is not gaining the same traction as sexuo-gendered representation in mainstream media (e.g. television; film; advertising; social media) (Pounders and Mabry-Flynn, 2016). The majority of related studies concern responses to advertising among the LGBTQIA+ community and emanate from mainstream marketing (Akestam et al., 2018) and sociology (Nolke, 2018; Hensley et al., 2019) literature, with few studies within retail literature. The authors believe that there is considerable value in locating this research within a UK population with a focus upon retail brands.

Addressing diverse sexuo-gender identities can provide retail brands with a distinctive advantage. For example, Rosenbaum et al. (2015) found that gay retail employees had a positive impact on the instore experience of female consumers, within hedonistic playfulness and innocuous sexual flirtations that increased trust, loyalty and consumer satisfaction. Rosenbaum et al. (2017) note that retailing academics are turning their attention to researching gay retail employee value but, also, acknowledge the lack of attention within academic retail literature to a wider, sexuo-gendered understanding. The value of retail employees as frontline ambassadors of the retail brand is widely accepted (Quach et 
al., 2017). Quach et al. (2017) advise that embracing diversity (age, ethnicity, gender and perceived sexual orientation) may attract a more diverse customer base. Issues of diversity become more contentions when retailers appease the needs of more traditionally defined cohorts (e.g. through a lack of engagement with consumer rights around access (e.g. toilet facilities; changing rooms; etc.) (see Lui and Minton, 2018). Other service-orientated industries, such as tourism and events are examining inclusivity via sexuo-gendered understandings (Hahm et al., 2018). It would seem remiss, therefore, for retailers to ignore this perspective.

Lui and Minton (2018) found that consumers react negatively to retailers displaying religious values and this may be an indication of the diffusion of progressive ideologies that embrace diversity and tolerance (Quach et al., 2017). Retailers should consider the implications of marketing retail brand values, to avoid alienating potential consumers. Understanding how consumers interpret and respond to sexuo-gendered imagery offers, therefore, particular advantage (Snyder, 2015). Therefore, this research will utilise photoelicitation to explore consumer perceptions of LGBTQIA+ imagery which has been used in marketing to better understand how this informs constructs of retail brand value.

Assuming that recognising and servicing diversity within retail markets is a valid ambition, this paper argues that a move towards full inclusion for all sexuo-gendered identities within societal discourse offers the opportunity for retail brand values to play a positive role in diffusing these concepts through mainstream consumer society. This research will be of interest to retailers who seek to signal a progressive brand view of sexuo-gendered identities in marketing activities that appeal to both transnormative and more mainstream consumers. The research adopts the stance that sexuogendered identities are socially constructed (Sha et al., 2007) and as societies move to be visibly more diverse and accepting of transnormativity, there are opportunities for retailers to embrace diversity to illustrate a progressive stance.

Consequently, the aim of this exploratory research is to examine the perceptions of mainstream UK consumers towards sexuo-gendered identities, as represented within retail marketing communications. The objective of the paper is to explore the value of developing more progressive, inclusive brand values to support effective, retail brand communications. The literature review examines the nature and value of various representations of gender and sexuality within society, marketing and retailing. The methodology explains the value of this small-scale, sexuo-gendered sample as a basis for this interpretivist, social-constructivist viewpoint. Findings are presented within a discussion of the evident, differential priorities of different identity groups and the value of this knowledge to informing retail brand value creation, strategy and practice.

\section{Literature review}

\section{Representations of gender in a marketised Society}

Within societal discourse, perceptions of 'genderedness' are grounded within everyday lives, constructed through individuals' perception of and engagement with objects, symbols and commodities (McCracken, 1990). This offers opportunities for positioning products and activities that appeal to consumers more directly, yet it also reinforces notions, assumptions and expectations of gendered stereotypes (Grau and Zotos, 2016). For example, 'nappies (diapers) were once simply 
squares of towelling but today's disposable varieties are marketed in two different shapes, one for boy babies and the other for girl babies, and the packages that they come in may well be coded in blue and in pink' (Crisp et al., 2013: 43). The temptation for marketers is clear - to assign characteristics to offerings that differentiate genders, despite gender-neutral, utilitarian product attributes. Such approaches narrow notions of how gender is defined, displayed and performed (Preziosi, 2009) and often conform to a patriarchal ideology, particularly as females are presented in a decorative role (Grau and Zotos, 2016). These issues, in part, underpin postfeminist arguments that reject prescribed, stereotypical constructs of gender, sexuality, femininity and masculinity (Lewis et al., 2017), proposing that such conceptualisations are built upon a flawed and biased patriarchal society of meanings.

More recently, consumer campaigns, such as 'Let Toys be Toys', 'Pink Stinks' and Mumsnet's 'Let girls be girls', have challenged retailers to move beyond gendered products (Levinson-King, 2008). A few retailers have responded with gender-neutral products, including fashion ranges (Saner, 2017). Whilst this has demonstrated retailers' willingness to engage with societal issues around gendered identity, it is still some way from broaching wider issues around sexuo-gendered diversity and, more specifically, identities that represent the LGBTQIA+ community (Kitzinger, 2001). Um (2016) found that gender role beliefs were higher in males than females; therefore, this research explores how postfeminism ideology has progressed to include minority identities. In particular, it considers how identity diverse imagery is perceived by mainstream consumers, within a social identification approach (Turner, 1985). By understanding the discriminatory bias inherent within consumers' construction of identity-relevant realities, marketers may be better able to map offerings to a seemingly hyper-fragmented consumer space identity (Schofield and Schmidt, 2005).

\section{Mapping social identities to markets - a social psychological perspective}

Theories of social identification explain the nature and role of individuals' identity as a driver of their cognitive and behavioural relations with others (Turner, 1999). Typically, these theories propose a range of priorities. At one end sit the group dominance theories (e.g. Festinger's Social Comparisons (1954) and various 'social' models) that see society and, therefore, marketing as a driver of behavioural conformity. At the other end, the individual dominance theories (e.g. Turner et al.'s Selfcategorisations (1987)) propose that all behaviour is dependent upon the cognitive choices (conscious or unconscious) made by each person. Between these, there is a broader set of ideas, located around Social Identity and Social Categorisation theories (e.g. Tajfel, 1982). These perspectives offer a useful space to understand consumers, as they appreciate the role of the consumer in determining identifications but, also, appreciate that often this identification is dependent upon the existence of clues or markers of expected position, such as those provided by existing social and cultural groups (e.g. genders) (Dodd et al., 2000; Woodruffe-Burton, 1998).

In particular, social identity theory offers a useful perspective on intergroup discrimination (see Turner, 1999), postulating that individuals categorise themselves and others into social segments, where they find a commonality with others who have similar characteristics or common bonds (Ivory, 2019; Gong, 2019; Hahm et al., 2018; Quach et al., 2017). Quach et al. (2017) and Grier and Brumbaugh (1999) note consumers' use of demographic cues to create meaning in retailing spaces and marketing, validating perceived membership of audience groupings which, in turn, increases affiliation with the retailer. This relates to a number of identity markers, such as race (Ivory, 2019; 
Quach et al., 2017), gender, sexuality (Oakenfull and Greenlee, 2005; Quach et al., 2017), values (Ritch and Brownlie (2016) and age (Peters et al., 2011; Cole and Yoon, 2008). Perhaps because consumers prefer seeing models consistent with how they perceive their own identity (Ivory, 2019; Gong, 2019; Quach et al., 2017), marketers' like to use easily identifiable, often stereotypical representations within their targeted marketing activities (Dotson et al., 2009).

One of the most accessible social markers is age (Woo, 2018), used by individuals as a heuristic device, to make sense of others through assumptions of shared experiences and expectations. For retailers, age is perhaps the first port of call when creating positioning strategies, offering relatively reliable, stereotyped boundaries for the provision of products and services. This reliance upon generational value perhaps over-rides a need to explore other drivers of cognition and behaviour. Researchers too are guilty of disregarding the variable effects of age when combined with other identities. There is a dearth of research that explores age and sexuality, though some evidence exists which explores the enduring effect of age upon sexuo-gendered drivers of behaviour (Dodd et al., 2005). The notion that older males are less tolerant, whilst younger females are more accepting of difference also deserves further examination (Smithson, 2000) and exploring generational effects across sexuo-gendered identifications would seem to be of high value.

Yet, Nölke (2018) questioned the value of using sexual orientation for target marketing, because much of the advertisers' understanding may be constructed within stereotypical assumptions that exclude the spectrum of sexuo-gendered identities. Gong (2019) and Nölke (2018) posited that minority sexuogendered identities, such as genderqueer, 'femme' males, 'butch' lesbians, bisexuals and transsexuals are invisible in media representations. Further, similar to heterosexual advertising, they suggested that lean youthful identities are preferred by marketers, to sell a sense of perfectionism rather than presenting destabilising gender and sexual identities that challenge social narratives. In particular, Nölke (2018) found that gay and lesbian portrayals dominate sexuo-gendered marketing, whilst other identities from the spectrum either remain invisible or are heteronormatively constructed. For example, transsexuals portrayed in mainstream advertising tend to be male-to-female transitioning to achieve a stereotypical feminine appearance. This hyperfemininity, Nölke argues, reaffirms a gender binary position as well as trivialising transfemininity. Yet, reaffirming gendered binaries has been central to marketing, serving as a cultural text that dictates gendered commodities, socially acceptable roles, behaviours and expectations (McCracken, 1990).

Indeed, marketing provides a social commentary on how identity should be constructed (Grau and Zotos, 2016). Yet this does not speak to growing numbers of consumers who experiment with heteroflexibility (e.g. straight men who sleep with other men), gender-fluidity and non-binary (those who do not want to be defined by a gender) or asexuality (those who have no sexual feelings) (Nölke, 2018). Following Nölke's (2018) questioning of who marketers seek to appeal to, this research seeks to explore consumers' understanding of contemporary marketing imagery and map this against a social identity framework to enable more practical value for retailer brand values. Consequently, it would be logical to explore perceptions of other members of the sexuo-gendered community that are represented in marketing. 


\section{Sexuo-Gendered identities in retail marketing}

Although retailers and marketers have long recognised financial opportunities in attracting sexuogendered consumers (Ivory, 2019), even lesbian and gay marketing imagery has remained outside of mainstream advertising to avoid negative responses from heterosexual consumers (Ivory, 2019; Gong, 2019; Um, 2016; Dotson et al., 2009). In mainstream marketing, symbols and markers that have meaning for the lesbian and gay community were used to subtly attract lesbian and gay consumers, remaining unobserved by mainstream consumers (Ivory, 2019); a strategy termed 'gay window advertising' (Kates, 1999). Although this has enabled retailers to attract lesbian and gay consumers without alerting heteronormative consumers, by using masculine, white middle-class gay men and feminine, slender, beautiful lesbians (Kates, 1999), it has contributed to a lack of diversity and inclusivity (Tsai, 2012). Heteronormative imagery may appeal to mainstream consumers but also continues to relegate sexuo-gendered identities to the fringes of society. As societal attitudes have become more accepting of same sex relationships (Ivory, 2019), mainstream organisations are beginning to illustrate their support for sexuo-gendered communities (Grau and Zotos, 2016) by featuring gay, lesbian and trans couples (for example, American Airlines; Abercrombie and Fitch; Proctor and Gamble; Dolce and Gabbana (see Ivory, 2019)). As mainstream marketing provides a wider reach than other, segment-specific channels, this not only extends market opportunities but, also, authenticates sexuo-gendered communities within wider society (Ivory, 2019; Gong, 2019; Nölke, 2018) as 'legitimate customers' (Sender, 1999: 175).

Underpinning mainstream consumers' acceptance of sexuo-gendered imagery is the acceptance of sexuo-gendered lifestyles; consumers with anti-homosexual attitudes prefer heterosexual imagery (Ivory, 2019; Dotson et al., 2009). For social identity theorists, this is typical of in-group and out-group processes, where the parameters of membership are confirmed via specific, value-laden, perceived behavioural characteristics. Once identified, the fortunes of the individual become bound with the fortunes of their in-group and the drive to derogate out-group members becomes an imperative to support self-esteem and well-being (see Turner et al., 1987). Discrimination is seen as natural and valued. Oakenfull and Greenlee (2005) examined mainstream, gay and lesbian perceptions of explicit and implicit gay and lesbian imagery and found that the homosexual audiences responded positively to both, which aligns with social identity-based explanations of preferences for imagery that reflects self-characteristics. Concurrently, the heterosexual audience felt alienated by explicit same-sex imagery, suggesting that inclusion of explicitly sexuo-gendered identities in marketing media reduces brand approval ratings in heterosexual audiences (Hester and Gibson, 2007).

On this evidence, the choices for marketers would appear to be fraught with risk. There is also risk, however, in continuing to alienate sexuo-gendered identities (Schofield and Schmidt, 2005). The clue to negotiating these choices may lie in evaluation of the nature and prominence of such imagery. For instance, Dotson et al. (2009) question what is meant by implicit/explicit. The implicit imagery used in Oakenfull and Greenlee's (2005) research is a beer advert with a pink triangle and a rainbow flag with the slogan 'Another one coming out', whereas the explicit image was a fashion advert with a same sex couple kissing on the cheek or forehead. As Dotson et al. (2009) point out, neither are particularly explicit; rather, this may be responsive to the lack of same-sex couples showing affection in mainstream media. Dotson et al. (2009) advanced this research by examining perceptions of overtly gay, lesbian and straight imagery - couples in intimate positions that featured in fashion adverts, as 
well as ambiguous imagery. Consistent with Oakenfull and Greenlee (2005), they found heterosexual males and females preferred ambiguous homosexual imagery and neither reacted well to erotic heterosexual or homosexual imagery, which the researchers attribute to saturation of provocative imagery in fashion advertising. Although this research was carried out a decade ago, it finds support through Um's (2016) more recent research.

Dotson et al. (2009) also found that heterosexual males react to gay imagery less favourably than heterosexual women respond to lesbian imagery, suggesting that women are more accepting of samesex relationships. This could be a reflection that lesbians are less visible and/or less conspicuous in marketing (Abelove, 2012). Herek (1988) posited that gendered ideologies built around heteronormative, hegemonic masculinity, lead to a rejection of gay males to affirm heterosexual masculinity by heteronormative society. Those studies are now dated, as illustrated by the participants in Hester and Gibson's (2007) research who describe the inclusion of sexuo-gendered imagery as a new concept. As sexuo-gendered identities have a greater presence in contemporary, mainstream society it could be assumed that acceptance is increasing (McIntrye, 2018; Nölke, 2018). This could also be reflected in assuming that younger cohorts are more tolerant of diverse sexuogender (Smithson, 2000). Yet, more recently, Ivory's (2019) participants also presented lower tolerance of gay imagery than lesbian imagery. Moreover, Oakenfull and Greenlee (2005) found that heterosexual men respond more favourably to lesbian than gay advertisements. Dotson et al. (2009) suggest that lesbian imagery carries more erotic capital for heterosexual males and this could reflect patriarchal assumptions that female identities and sexuality are for male pleasure, particularly as Nölke (2018: 226) suggests that, in marketing, lesbians are 'formulaically straightened to adhere to heteronormative forms of femininity'.

Lesbianism carries less of a threat to heteronormative hegemonic masculinity, yet little is known of how this notion of 'hypersexualised lipstick lesbianism' (Nölke, 2018: 226) impacts upon female identity constructs. More recently, Ivory (2019) found that participants who accepted homosexuality, regardless of their own sexuo-gendered identity, preferred gay and lesbian advertising over heterosexual. Similarly, Um (2016) found that gay-themed advertising improved a brand's reputation, increasing purchase intention and concludes that tolerance of sexuality is the important factor, rather than the explicitness or implicitness of the imagery. As gay and lesbian consumers also prefer to see themselves represented in marketing, Ivory (2019) suggests this is an effective strategy for increasing audience engagement as society becomes more tolerant to sexuo-gendered communities. There are fears, however, that brands are employing a transactional approach to the use of sexuo-gendered imagery in the pursuit of higher brand equity and financial gain, rather than seeking the development of meaningful relationships across diverse audiences (Ivory, 2019). This has been evident in the use of transgender models and gender-neutral fashion ranges.

\section{Transfeminism and Gender-Neutral identities in retailing}

Transfeminism seeks to alleviate prescribed gender and sexuality confines by embracing the notion of intersex bodies and including equal rights for all representations of femininity (Erickson-Schroth, 2014). The discourse around transgender is less developed than that around sexuo-gendered identities and this is a cohort that continues to experience victimisation and discrimination (Testa et al., 2012). Stotzer (2009) believes this is due to societal confusion over what defines a transgender 
person. Similarly, when McPhail and DiNitto (2005) investigated transgender discrimination, they had to define transgender and explain the distinction between gender and sex to almost every participant. Although confusion about transgenderism filters into postfeminism (Knauer, 2007), transfeminist movements have enriched the debate around gender-constructs and heightened social awareness for transgenderism in society (McIntyre, 2018). Given that McPhail and DiNitto's (2005) research carried out over a decade ago found little understanding of transgenderism, it would be timely to investigate how transfeminism has impacted on mainstream consumer perceptions and whether there is increased acceptance of the transgender community.

Retailers are still entrenched within dualistic, gendered societal norms and the transgender community therefore experience conflict by having little choice but to select masculine or feminine products, which they feel misrepresent their identity (Levi, 2006). Although some retailers, such as Zara and ASOS, have introduced gender-neutral collections, the response is mixed. Some consumers have enjoyed the freedom from conforming to gendered expectations but acknowledge that it is more acceptable for women to look 'tomboyish' than for males to wear dresses, skirts or blouses (Kane, 2006). In particular, John Lewis, who stopped segmenting children's clothing into girls' and boys' categories to avoid reinforcing gender stereotypes (Geddes et al., 2017), have been both applauded and criticised for an approach that is at 'the frontline of modern gender politics' (Sender, 2017). Viewing gender-neutral clothing through a postfeminist lens offers the potential to relieve women of the hypersexualised erotic imagery that is often prevalent in the media, especially within fashion (Rysst, 2010) and food (Stewart and Cole, 2019) marketing.

The literature illustrates how marketing contributes to patriarchal sexuo-gendered constructs. This has resulted in the development of new social narratives that illustrate progressive acceptance for gendered roles. Whilst this embraces diversity and inclusivity, critics believe that the journey still has some distance to travel to fully embrace minority identities that are perceived to threaten patriarchal social systems.

\section{Methodology}

The preceding review of sexuo-gendered identities in retailing and marketing proposes exploration within a social identity framework. Few studies exist which apply this theoretical perspective to gender and/or sexuality within the retail or marketing context (Ivory, 2019; Dotson et al., 2009). In order to gain rich and detailed data concerning consumer perspectives of sexuo-gendered identities, this exploratory research adopts an interpretivist approach (Yin, 2003). Interpretivism recognises that social constructs emerge through idiographic experiences that are subjectively evaluated (KakkuriKnuuttila et al., 2008; Nölke, 2018). An ongoing narrative would offer insight into the influences that shape notions of gender and sexuality, given the discord described in the literature review. Focus groups were created to facilitate in-depth discussions and debate, with the purpose of facilitating insights into the beliefs, behaviour and attitudes of respondents (Langford and McDonagh, 2003). To enable social identifications to be observable within this context, and to better understand how sexuogendered identities suffuse within society, two generational cohorts were examined: Generation-X and Generation-Y. As Smithson (2000) advises, minimising the diversity of focus groups reduces the potential tensions of contrasting views. Hence, the generational cohorts were further divided by dualistic gender, making four demographically homogenous focus groups in total: 
1. Generation $X$ females (aged $42-48$ years; all heterosexual)

2. Generation $Y$ females (aged $18-21$ years; all heterosexual)

3. Generation $X$ males (aged $42-48$ years; all heterosexual)

4. Generation $Y$ males (aged 18-21 years; all homo/bisexual)

Smithson's (2000) identification of lower tolerance in older male cohorts and higher tolerance in younger and female cohorts is given space within this sample frame. The participants were recruited via a snowball sample, through personal contacts and social media. A benefit of adopting snowball sampling is that the participants have some familiarity with one another, which can aid discourse. Additionally, snowball sampling enabled access to participants with similar lifestyles and ideology, offering depth within the discussion (Berger and Luckmann, 1966). The respondents were required to meet the minimum requirements of age and dualistic gender identity. Sexuality was not a prescribed criterion but was recorded (with permission) and, subsequently, was used to further differentiate focus groupings. All participants were UK nationals.

Discussions were audio-recorded and transcribed and the focus groups each lasted between 45 and 90 minutes, generating substantial amounts of qualitative data. To stimulate discussion, the participants were shown advertising imagery of fashion retail brands that portray gay, lesbian and transgender individuals (a description of each advertisement is recorded in Table 1 below). The imagery was selected because it was used by brands to support Pride (the annual celebration of sexual and gender diversity) or to illustrate progressive brand value (Ivory, 2019; Grau and Zotos, 2016). Therefore, the imagery challenges perceptions of in-group and out-group identities, especially as the images present more explicit content, such as intimacy between same gender/transgender models (Dotson et al., 2009). As two of the images include transgender models, typically underrepresented in mainstream communications, the research seeks to update Testa et al.'s (2012) assumption that the transgender cohort are still unaccepted, as well as provide insight into what is considered explicit or challenging lifestyles. All of the imagery emerged from well-established international retail brands. Although Playboy is primarily an American men's lifestyle and entertainment magazine, there are associated commodities sold with the brand logo that signify a particular lens of gender and sexuality - therefore the inclusion of a transgender model by this brand challenges notions of hypermasculinity.

\section{Insert Table 1: Images used to stimulate discussion}

Thematic analysis across the four focus groups enabled the data to be examined for identifying recurring concepts, resulting in the generation of four themes that are presented next:

1. Generational Perceptions of Sexuo-Gendered Imagery

2. Socionormative Perceptions of Sexuo-Gendered Imagery

3. Perceptions of Transgender Imagery and Gender-Neutral (Clothing - Products?)

4. Perceptions of Gender Binary Imagery

\section{Findings and Discussion}


The research seeks to examine consumers' perceptions of retail brand representations of genderoriented and/or sexuality-oriented identities and utilises a dual-generational and dual-gendered sample. This section explores the perceptual data within four broad viewpoints, as noted within the literature review, each framed within a social identity understanding. First, age is considered, through generational effects upon perceptions of sexuo-gendered imagery. Second, traditional, socialised expectations are explored within socionormative effects upon perceptions of that imagery. Both of these moderators are then brought to a sharper focus, through consideration of perceptions of transgender imagery, gender-neutral products and binary gender Imagery.

\section{Generational Effects upon Perceptions of Sexuo-Gendered Imagery}

There was consensus across all focus groups that sexuo-gendered identities were more visible in society and this was recognised when seeking to appeal to younger generations:

It's more accepted now to be gay, bisexual or transgender. Before [marketers] wouldn't have used a transgender or gay person because it would have put [consumers] off. (2A)

Fashion brands are pitching to a younger audience; as generations evolve, people's intolerance is reducing and people are far more open to people of all sexualities. (1A)

Although indicative of increasing acceptance, the above quotes emerged from the female-only focus groups (both Generation-X and Generation- $Y$ ), supporting notions that female identities are less threatened by sexuo-gendered representations. This may also be reflective of the evolution of femininity portraying diverse role models over the last few decades (Grau and Zotos, 2016), with this fluidity facilitating acceptance of heterogeneity and heteroflexibility. For some, this presumption that sexuo-gendered identities are becoming more acceptable came with age-based ownership rights:

Our generation [Y] is the generation that's coming to terms with [gender-fluidity]. Younger [people] don't know any different but we are the starting point. Anybody older, they don't really understand it. (2B)

This quote illustrates that discourse around gender-fluidity for Generation- $Y$ is less constrained by gendered stereotypes, perhaps a consequence of gender-neutral campaigns. For the Generation- $X$ males, however, repositioning gendered social conditioning limited their ability to embrace fluidity:

I don't really understand the concept [of] 'gender-neutral.' I was brought up to think cars are for boys and dolls are for girls. (3C)

The traditional approach to advertising commodities by gender has constructed societal notions of gendered expectations (Grau and Zotos, 2016; Crisp et al., 2013; McCracken, 1990) that lead to assumed roles, activities and characteristics (Grau and Zotos, 2016; Schroeder and Zwick, 2004), despite some brands challenging stereotypes. Generation-X males expressed discomfort with transnormativity and, emboldened by collective opinions, vocally advocated abhorrence for the homosexual imagery within mainstream media:

If people want to look at [non-heterosexual imagery in advertising] they can look at it in their own time. Forcing it in advertising or on the front of magazines is just unfair. It assumes that 
everyone wants to see that. If you are going be so bold as to put [non-heterosexual imagery] into the public eye, you've got to expect people to say something about it. (3B)

All this special treatment towards [non-heterosexual communities]. It's not equality, it's onesided. (3A)

Such quotes illustrate this cohort's enduring discomfort around transnormativity and perceived disenfranchisement from societal norms. Consider participant 3B's reference to the imagery as 'forced', 'unfair' and 'bold', alluding to a preference for non-heterosexual identities remaining excluded from mainstream society (Lombardi et al., 2002) and to a low tolerance of progressive identity construction. Similarly, 3A claims that accepting diverse identities is a 'one-sided' approach, which can be interpreted as being one or the other: as in male or female, rather than gender/sexuality fluid. This fixed, narrow lens facilitates neither a multiplicity of gendered identities, nor a fluidity for adaptation. As the imagery presented was both implicit and explicit, the quotes support Um's (2016) assertion that tolerance towards heteroflexibility and transgenderism is more important than the explicitness of the imagery. It also assumes that equality equates to heteronormative constructs of gender that are a key component of the hegemonic masculinity that is currently embedded in society (Connell, 1987). The challenge for retailers is to reflect this tolerance within their mainstream imagery on an ongoing and not simply occasional basis.

The generational boundaries visible within these data offer evidence for a social identity understanding, with in-group versus out-group language and sentiment clearly communicated. Tactics seem to include the derogation of out-group priorities, claims of 'unfairness' from all sides and, further, the consolidation of a 'them $v$ us' rationale for answers.

\section{Socionormative Effects upon Perceptions of Sexuo-Gendered Imagery}

Such positions move into sharper focus when viewed through the lens of traditional social groupings that espouse adherence to traditional constructs of gender/sexuality, as expressed by the participant who adhered to the teaching of Hinduism:

I don't think [homosexuality] is normal. That's not how we were brought up and I don't think it's acceptable. I would avoid [homosexual imagery]. (3C)

Previous research (Dotson et al., 2009; Oakenfull and Greenlee, 2005) found negative consumer attitudes to homosexual advertising, yet this did not identify a link with religion. Although Ivory (2019) reported that Christian evangelist organisation Franklin Graham and the American Family Association both reacted negatively to advertisements that featured gay and lesbian couples, these organisations both represent attempts to maintain traditional patriarchal dualistic social systems. Referring to gender-fluidity and same-sex relationships as 'not normal' and contrasting to 'how we were brought up' illustrates a lack of penetration of progressive identity construction beyond dualistically gendered identities and a preference for patriarchal social systems (Schroeder and Zwick, 2004). This is, however, incongruent with societal developments that are portrayed in mainstream advertising as embracing transnormativity, as evident in TV and social media (McIntrye, 2018; Nölke, 2018). Further, over the last decade, consumer campaigns have sought to move beyond the commodification of 
dualistic gendered constructs to embrace multiple gendered roles (Levinson-King, 2008). This implies firstly, that the infusion of transnormativity is slowly superseding religious teaching, as evident within the other three focus groups who expressed tolerance for diversity as well as the increased numbers of the UK population categorising themselves as having no religion (BBC News, 2017). Lui and Minton (2018) advised that consumers found retailers displayling religious values as unappealing. Concurrently, many religions are exhibiting more tolerance towards sexuo-gendered communities (Hunt, 2018). Secondly, current and future generations are more exposed to socialisation pressure to accept fluidity and diversity of identity-formation, which will also lead to increased tolerance in future generations (Um, 2016). Supported by legislation for LGBTQIA+ rights, especially the right to live free from discrimination, new notions of 'normality' become embedded within mainstream society, offering heterogeneous identities as the new norm (Nölke, 2018).

Of course, all societies are culturally and temporally bound and less tolerant sentiments may persist to varying degrees of intensity and longevity (Hester and Gibson, 2007). Consider, for instance, the higher prevalence of homophobia reported within Asian countries relative to other countries (Nölke, 2018). Preferences for sexuo-gendered identities to remain on the fringes of society may explain the prevalence of 'gay window advertising' being used to avoid brand rejection (Tsai, 2012). Yet, marketing can play a role in democratising traditional notions of sexuo-gendered appearance (Grau and Zotos, 2016). Further, if retailers do not embrace diversity, they risk being rejected not only by the LGBTQIA+ community but, also, by younger more progressive consumers for failing to represent the diversity of identities (Ivory, 2019; Um 2016; Abelove, 2012). The consequences of such thinking are clear and noted within this cohort, through assertions that retailers should not discourage acceptance of sexuo-gendered identities:

If a company negatively talked against LGBT rights and women's rights, it would deter me from consuming their products. (4A)

[Sexuo-gendered advertising] is beneficial, it's raising awareness]. (1E)

It is perhaps unsurprising that women support advances in sexuo-gendered identities (the literature reported greater tolerance for homosexuality from females) (Dotson et al., 2009). Additionally, postfeminism seeks to free identity from sexual scrutiny within patriarchal ideology, politicising and democratising identity, fashion, commodities and ideology (Sender, 2017). Although Hester and Gibson (2007) found that negative attitudes towards the LGBTQIA+ community were reflected in consumption, similar to the findings from Um (2016), this research has found a positive response to embracing diversity and that brands who publicise negativity towards sexuo-gendered identities may risk being ostracised by consumers. The fashion industry is renowned for progressive and provocative advertising, yet much of this supports patriarchal gender-constructs. This research suggests that advertising can challenge societal discourse, particularly around notions of clothing.

From a social identity perspective, normality is 'achieved' via adherence to the perceived norms of the in-group and distancing from out-groups. Within this framework, it is easy to see the power of established traditional groupings and ideologies. From the intense, unrequested socialisation of family, to devolved socialisation of religion and the sought influence of friends, the socionormative pressure will weigh heavily upon consumers as they seek to negotiate routes to positive self-esteem 
and coherent identities. For retailers, adherence to existing stereotypical representations (through imagery, product provision, accessibility, etc.) simplifies this journey but, simultaneously, compounds the validity of a narrow and non-progressive system. The challenge in projecting modernised retail communications is to broaden and challenge ideals of normality to respond to the needs of an increasingly self-aware and socially conscious consumer.

\section{Perceptions of Transgender Imagery and Gender-Neutral Products \\ Younger consumers' acceptance of gender/sexual fluidity filtered into embracing transgender imagery, recognising this was important to promote societal acceptance:}

I think it's really cool that Playboy have a transgender woman in their marketing. [It is] something that's still not accepted these days and it's important that they push that. (4A)

Not only were the Generation-Y participants aware of transgenderism, illustrating a progressive societal awareness for the community, they were also keen to embrace diverse identity-construction and move beyond discrimination for this cohort (McIntyre, 2018; Nölke, 2018; Testa et al., 2012). This is especially pertinent when considering that Playboy is already a gender-contentious forum, with arguments as to whether Playboy represents the objectification or empowerment of women, within patriarchal assumptions of femininity and sexuality. Yet, for the Generation-Y cohorts, this was considered as the first stage in societal acceptance of moving beyond gender binaries (Nölke, 2018). Consequently, this research reports preferences for embracing diverse identities rather than adopting the 'gay window advertising' that masks or disembodies sexuo-gendered communities, as evident in opinions that perceived growth in products and services that cater for diverse identities:

[Gender-neutral clothing] has only started to evolve and maybe in ten years there will be a section in Superdrug for men's makeup and [fashion] shops which are all gender-neutral. (2A)

Although acceptance of gender-neutral fashion was evident in the Generation-Y cohorts, there was clearly a perception that mainstreaming products, such as fashion and make-up, for non-traditional audiences is some way off. There was also an expressed disappointment by the Generation-Y males (which included gay participants) that, currently, gender-fluid or gender-neutral products are a superficial response to embracing diverse identities and not one which would enable a creative identity-construction:

I saw Zara released a [gender-neutral] line of, just grey jumpers [and] bland baggy clothes. (4C)

The notion that gender-neutral is interpreted as 'bland' and 'grey' illustrates a lack of creativity in embracing diversity, neither challenging gender or sexual identities. The collection may appeal heteronormatively, but the use of neutral colours plays to traditional assumptions while baggy clothes mask gendered body-shapes (Preziosi, 2009) and collectively reinforce socially acceptable hegemonic gendered fashion codes (Nölke, 2018). Consequently, the collection perpetuates the myth that men should not wear feminine clothing and women should refrain from masculine garments (Geddes et al., 2017; Kane 2006). 
Rather than becoming more accepted in society, it seems that deviating from gendered conformity is still perceived as socially unacceptable. It could also be argued that the acceptance of diverse identities indicates a trajectory:

It's fine for women to wear trousers to work, but it would be weird for a man to turn up in makeup and a dress. They'd just laugh at them. (3B)

Within many cultures, women are discouraged from wearing trousers (or equivalent 'male' clothing) and considered 'queer' if they adopt male clothing. The fear that feminine commodities would undermine societal norms for hegemonic masculinity (Connell, 1987) transferred to ensuring that their children aligned with prescribed gender clothing and commodities. Cottin Pogrebin's (1980) identification of parents' reluctance to allow their children to experiment with their identity, due to fear of association with homosexuality, seems still to be prevalent today. This preference to construct a conventional appearance was not only male driven, one Generation-X female expressed her fear that:

If I was wearing it, and people were staring at me, I would be like: oh, do they think I am ... (1C)

This fear of clothing signifying unwanted sexuo-gendered identity was noted by Takács (2006), who also confirmed the drivers of fear of ridicule and personal safety. This notion could emerge from sexualised fashion marketing that prioritises female appearance in terms of propensity to attract males. The quote also supports Tsai's (2012) assertion that marketers are reluctant to deviate from societal norms by playing with gender-fluidity, for fear of rejection from mainstream consumers. This assumes, however, that commodities exist primarily to consolidate gender binaries, rather than encourage freedom from patriarchal social structures, as expressed by a Generation- $Y$ female participant:

It's a human being advertising a piece of clothes. Who cares about their sexuality? There are definitely some closed-minded people who have a problem with it. (2A)

This quote suggests that meaning constructed around clothing should be acknowledged as benign. Yet, social narratives imbue upon constructed pieces of fabric social and political ammunition that restricts and confines creative expression to adhere to patriarchal ideologies within dualistic gender binaries (Schroeder and Zwick, 2004). Societal acceptance of sexuo-gender depends on transcending notions of gender binary to embracing diversity.

By emphasising the nature of choice and potential negative effects of choosing from restricted retail offerings, this discussion challenges social identity approaches. If retailers offer consumers the chance to construct identity via product adoption but there is insufficient variety to cater for some identities, the consumer may exist within an incomplete evidence base for their identity. Whilst this is not necessarily the retailers' fault, it suggests that many retailers are missing opportunities to make this process better for all by broadening offerings and, therefore, identities. Retailers are challenged, therefore, to create retail formats that are not simply based around dualistic gender identities but 
respond to the challenges of managing diverse identities, through non-gendered product categorisation and service.

\section{Perceptions of Gender Binary Imagery}

Noting how the portrayal of women has transcended from domestic roles in the household to powerful and independent societal figures (Grau and Zotos, 2016), demonstrated awareness of the potential fluidity of gendered-identities:

I suppose [women] are portrayed [as] more empowered. Obviously, it's good for them. (3C)

I think feminism has encouraged a lot of women to work and be independent; before, women were just encouraged to stay at home and look after the kids. Nowadays it's changing and in my opinion that's good. Women should be free to do what they want and have the same rights as men. (3E)

That female 'empowerment' was perceived as enabling progressive advancements that support equality in gendered roles, both within and out with the home, was noted across all four focus groups, correlating with Akestam et al.'s (2017) assertion that marketing illustrates women's' evolvement in society. Yet, for the female focus groups, this was considered to be superficial, to avoid being criticised for creating gender stereotypes. The above quotes both emerged from the Generation-X male focus group and illustrate, not only embracing gender equality, but actively supporting the emancipation of women. In contrast, the Generation- $X$ female focus group did not recognise feminism as releasing them from gendered expectations:

I don't think that feminism has had any impact whatsoever. Things are still marketed the same way as they always have been. (1A)

It is interesting that the Generation- $X$ male focus group perceive advancement over the last few decades (Grau and Zotos, 2016), yet this is not experienced by the female focus group. Generation-X women may consider gendered roles as evolving, but this exists among social norms that prescribe assumptions of gendered appearance, as advertising still focuses on 'young, pretty, attractive women' (1A). This was also the opinion of the Generation- $Y$ women when reflecting on marketing imagery:

This will make you sexy; this will make you beautiful; this will make men fancy you. (2A)

Despite greater societal discourse around gender equality, both female cohorts expressed cynicism for the way in which their gender is represented in marketing. The narrow vision of femininity illustrates there is little understanding for how women still struggle with restrictive identity pressures dictating their appearance and body-shape (Grau and Zotos, 2016). Patriarchal assumptions that female identity aesthetics exist for male pleasure (Bates, 2019) is something that is contested by both postfeminism (Lewis et al., 2017) and transfeminism (Erickson-Scroth, 2014). That both female cohorts present perceptions of objectification, suggests that whilst advertising may acknowledge gender equality advances and, to an extent, utilise this movement to reflect the synergy within society (Grau 
and Zotos, 2016; Levinson-King, 2008), advertisers still peddle the same dated narratives to elicit sexual desire (Rysst, 2010).

Although brands are more astute to avoid criticism of gender stereotypes, this could be due to the prevalence of feminist and equality debates in society that heighten sensitivity to the issues or, perhaps, subliminal messages that female identities still have to conform within patriarchal assumptions. Nölke (2018: 239) noted that even lesbian representation in advertising depicted heteronormative feminine ideals for the 'straight male gaze'. Within a patriarchal society there are also links to hegemonic masculinity (Connell 1987) and hyperfemininity (Nölke 2018), both of which have implications for sexuo-gender. Similarly, patriarchal assumptions of objectification and exploitation of appearance were considered to frame sexuo-gendered identities with sexual implications:

If you're a good-looking gay guy, they'll use you for sex appeal as well as promoting LGBT rights. (2F)

Although this quote was stated by a Generation-Y female, there is still the acknowledgement of using dualistic gender-normative representations that mimic heteronormative lifestyles, to maintain the boundaries of stereotypical masculine/feminine identities and avoid offending homophobic consumers (Schroeder and Zwick, 2004; Tsai, 2012; Kates, 1999). Additionally, there was cynicism that evolving attitudes towards acknowledging sexuo-gender in marketing and that gender-neutral fashion collections were more about increasing profits and the visibility of branding than progressing acceptance of the sexuo-gendered community:

I think that being too explicit [with the use of sexuo-gendered imagery]. [It] puts me off. [I feel that] they are kind of exploiting it. (4B)

It is interesting to note that this participant was a Generation-Y homosexual and yet he expresses disillusionment with sexuo-gendered advertising. This could be due to overly stylised imagery that falls under heteronormative narratives or simply that the overtly sexualised aspect of the imagery is less palatable for some. Such disingenuous approaches do not necessarily challenge social commentary on diverse identities, especially as it is recognised that promoting sexuo-gendered communities improves brand reputation (Um, 2016). Consequently, this could be considered an attempt to exploit the sexuo-gendered communities to maximise profits, with the potential to backfire.

Social identity theories assume that individuals are able to construct identities via imagination as much as by practice. Stereotypes from a major part in this process, as individuals cherry-pick characteristics that suit their desires. These data would seem to suggest that, for some at least, stereotypes employed by marketers and retailers are jarring and obtuse. The aim for retailers should be the mainstream inclusion of sexuo-gendered communication images which are not necessarily motivated by profit or brand visibility. Should retailers fail to keep pace with changing attitudes to such imagery and provision, they risk exclusion of potential consumers from their business. 


\section{Concluding Comments}

This research contributes to the extant literature by exploring mainstream perceptions of sexuogendered identities in mainstream media and, in particular, presents the perspective of UK consumers from a mixed sample of sexuo-gendered and generationally differentiated individuals. Some of the discourse in this paper concurs with research from the USA that confirms Generation-X males' intolerance of gay imagery (Um, 2016). The paper also illustrates an acceptance of sexuo-gendered identities by younger consumers (Gong, 2019). Specifically, this research progresses our understanding of gender binaries and how gender is portrayed in mainstream society. This research evidences perceptions of female empowerment. It also notes antipathy towards the paucity of sexuogendered identities and to the overtly sexualised imagery (both same-sex and heterosexual) of dualistic identities that prescribe constructs of hyperfemininity and hegemonic masculinity. Although the Generation- $X$ males endorsed female representations of empowerment and felt that this was positively progressive, this was within the confines of stereotypical patriarchal expectations representative of gender. This narrow view continues to be encapsulated within marketing and the Generation-Y focus groups expressed frustration at this superficial messaging.

Such positions offer support to a social identity conceptualisation. The younger cohort and the Generation-X females feel confined by patriarchal ideology, rejecting overly stylised imagery illustrating perfection and seek liberation for gender/sexual fluidity. This research advances social identity theory by illustrating consumer preferences for marketing that is representative of an inclusive ideology, diverse and non-discriminatory, rather than seeking similar characteristics mirroring their self-image. Specifically, social identity theory may struggle to move beyond representations of actual self within a fluid, non-traditional framework to include political ideologies as bases of identity. The theory may itself be locked within a biased, gender locked discourse. For this sample, this manifests as a cynicism for how identity is represented. Their discourse reveals an acceptance of sexuo-gender fluidity as a preference to move beyond restrictive binary labels. Nölke (2018) introduced the notion of moving beyond sexual orientation bases for market segmentation, because of the inherent reliance upon stereotypical gender binaries presented as perfection. This research supports Nölke's (2018) assumptions that younger consumers may prefer marketing that presents destabilising gender/sexual identities to create new binary constructs that challenge social narratives. This offers insight into how best to develop activities that increase affiliation with branding and marketing, whilst being mindful to avoid explicit imagery, which may threaten patriarchal and religious ideology.

Although the Generation- $X$ females displayed more tolerance towards sexuo-gendered imagery than the Generation- $X$ males, they sometimes delivered homophobic comments. They also expressed preferences to conform to patriarchal representations of femininity. For some, this was to avoid being mistaken as belonging to the LGBTQIA+ community. Their tolerance illustrates both a desire to avoid being discriminatory as well as seeking to avoid being discriminated against. Although they illustrate only partial acceptance of gender/sexual diversity, there was clear empathy for multiple sexuogender-constructs. In contrast, the Generation- $Y$ focus groups conveyed positive attitudes towards sexuo-gendered imagery, stating they would avoid retailers who did not support LGBTQIA+ rights. Whilst Generation-Y applauded the inclusion of sexuo-gendered diversity in marketing, there was criticism of the gender-neutral fashion collections for the lack of imagination for gender-fluidity. 
Whilst there was opportunity to embrace diversity and destabilise assumptions around gender/sexual identities, brands were believed to prefer to play safe within the confines of hegemonic social codes. This underpinned cynical assumptions that a brand's imperative was to exploit the suffusion of sexuogendered diversity, rather than embrace and support these communities.

There are clearly opportunities for retailers to utilise the edginess of sexuo-gendered identifications, both in imagery and in product development, to indicate progressive retail brand values (Rosenbaum et al., 2017; Rosenbaum et al., 2015; Quach et al., 2017) that appeal to transnormative and mainstream consumers. Contrasting with consumers negative perceptions of retail brands portraying religious values (Lui and Minton, 2018), the current model of using gender-heteronormative models seems outdated. This lack of representation of diverse sexuo-gendered identities does little to detach from the 'gay window dressing' (Kates, 1999) of contemporary campaigns and perpetuates the portrayal of an inferior woman alongside a dominant man (regardless of their sexuality or gender). Rather, social identity theory in this instance posits that ideology rather than physical attributes are sought by younger consumers. That is, retail marketing that represents a wider, inclusive spectrum of identities. Given that this research has illuminated progressive ideologies that encompass diversity and tolerance for inclusive retail marketing imagery, future retailing research should address this more widely. This is especially important as younger consumers appear to feel misrepresented by dualistic binaries.

\section{Limitations and Recommendations}

The research is limited by generalisability, as is typical of interpretative research. It should be acknowledged that this is a biased sample. Both the Generation- $X$ focus groups comprised heterosexual participants, as did the Generation- $Y$ female focus group and most had not continued education after high school. The Generation-Y male focus group consisted of two homosexuals, one bisexual and one heterosexual, who all attended university. It could be assumed that this diversified their social spheres. This does not represent consistent cohorts throughout all four focus groups, particularly as LGBTQIA+ representation was missing from focus groups one to three. This has a couple of implications: first, the Generation-X males did not taper their language to avoid conformation or discrimination and they may have moderated their tolerance if members of the LGBTQIA+ community were part of the group. Second, no respondent is treated as representative of all consumers affiliated to their grouping. For instance, many Generation-X males abhor homophobic views. Nevertheless, hearing directly from the LGBTQIA+ community in focus group four enabled the notion that sexuogendered imagery is cynically exploited and this was not identified in the other three groups. Further, the advertisement imagery presented was not necessarily related to all of the focus group demographics - the advertising was not designed to reach a Generation- $X$ male audience and this would have restricted a connection with the marketing message. Furthermore, the research is limited by the sexuo-gendered imagery available in mainstream media. This constrained the opportunity to present diverse identities for discussion. Consequently, this leads to recommendations for future research to expand the reach of research to explore how larger samples of sexuo-gendered consumers perceive identities used in advertising. This could also include attitudes towards gender-neutral products which would benefit product development and brand engagement. There are opportunities for expanding mainstream consumer research to examine the extent of acceptance for sexuogendered communities and, moreover, future research could include the effects of different cultural 
and religious bases upon consumer attitudes and behaviour towards sexuo-gendered imagery in advertising.

\section{References}

Abelove, H. (2012). "The lesbian and gay studies reader". London: Routledge.

Åkestam, N., (2018). "Caring for her: the influence of presumed influence on female consumers' attitudes towards advertising featuring gender-stereotyped portrayals". International Journal of Advertising, Vol. 37 No. 6, pp. 871-892.

Bates, K.R., (2019). "Experiences of Intimate Partner Violence among LGBTQ+ Individuals and the Perceptions of Professional Services". Texas State University, available from: https://digital.library.txstate.edu/bitstream/handle/10877/8991/BATES-THESIS2019. pdf?sequence $=1 \&$ isAllowed $=y$ (accessed 28 May 2020)

BBC News. (2017). "Majority of Scots say they are 'not religious'". BBC News, available at: https://www.bbc.co.uk/news/uk-scotland-41294688 (accessed 28 March 2019).

Berger, P. and Luckmann, T. (1966). "The social construction of reality. A treatise in the sociology of knowledge". London: Penguin Books Ltd.

Berry, C., Martin, F., Martin, L.C.S.F., Yue, A. and Spigel, L. eds., (2003). "Mobile cultures: New media in queer Asia". Duke University Press.

Cole, C.A. and Yoon, C. (2008). "Aging and consumer behaviour". In Haugtvedt, C. P., Herr, P. and Kardes, F. (Eds.), Handbook of Consumer Psychology. New York: Lawrence Erlbaum Associates. pp. 247-271.

Connell, R.W. (1987). “Gender and power". Stanford, CA: Stanford University Press.

Cottin Pogrebin, L. (1980). "Growing Up Free: Raising Your Child In the 80s". London: McGraw-Hill.

Crisp, J., Ferres, K. and Swanson, G. (2013). "Deciphering culture: ordinary curiosities and subjective narratives". London: Routledge.

Dodd, C.A., Clarke, I., Baron, S. and Houston, V. (2000). "'Looking the Part': Identity, meaning and culture in clothing purchasing - Theoretical considerations". Journal of Fashion Marketing and Management, Vol. 4, No 1, pp. 41-48.

Dodd, C.A., Linaker, A. and Grigg, N.P. (2005). "He's gotta have it: Shopping dependence and the homosexual male clothing consumer". Journal of Consumer Behaviour, Vol. 4, No. 5, pp. 374-389.

Dotson, M.J., Hyatt, E.M. and Thompson, L.P. (2009). "Sexual Orientation and Gender Effects of exposure to Gay- and Lesbian-Themed Fashion Advertisements". Journal of Fashion Marketing and Management: An International Journal, Vol. 13 No. 3, pp 431-447. 
Erickson-Schroth, L. ed., (2014). "Trans bodies, trans selves: A resource for the transgender community". Oxford University Press.

Festinger, L. (1954). "A theory of social comparison processes", Human Relations, Vol. 7, pp. 117140.

Geddes, D., Ungoed-Thomas, J. and Moore I. (2017). "John Lewis goes gender-neutral on childrenswear". The Times, available at: https://www.thetimes.co.uk/article/john-lewis-removesgender-labels-from-childrens-clothing-3kjzctsps (accessed 22 March 2018).

Gold, M. (2019). "The ABCs of L.G.B.T.Q.I.A.t". The New York Times, available at: https://www.nytimes.com/2018/06/21/style/lgbtq-gender-language.html (accessed 26 May 2020)

Gong, Z.H. (2019). "Crafting Mixed Sexual Advertisements for Mainstream Media: Examining the Impact of Homosexual and Heterosexual Imagery Inclusion on Advertising Effectiveness". Journal of Homosexuality, Vol. 29 No. 0, pp. 1-24.

Grau, S.L. and Zotos, Y.C. (2016). "Gender stereotypes in advertising: a review of current research", International Journal of Advertising, Vol. 35 No. 5, pp. 761-770.

Grier, S.A. and Brumbaugh, A.M., (1999). Noticing cultural differences: Ad meanings created by target and non-target markets. Journal of advertising, Vol. 28 No.1, pp.79-93.

Hahm, J., Ro, H.R. and Olsen, E.D. (2018). "Sense of belonging to a lesbian, gay, bisexual, and transgender event: the examination of affective bond and collective self-esteem". Journal of Travel \& Tourism Marketing, Vol. 35 No. 2, pp. 244-256.

Hensley, C., Diddi, S. and Hyllegard, K., (2019). "Millennial Consumers' Responses to Cause-Related Marketing in Support of LGBTQ Homeless Youth". Social Sciences, 8(8), p.240.

Herek, G.M. (1988). “Heterosexuals' Attitudes toward Lesbians and Gay Men: Correlates and Gender Differences". Journal of Sex Research, Vol. 25 No. 4, pp. 451-477.

Hester, J.B. and Gibson, R. (2007). "Consumer responses to gay-themed imagery in advertising". Advertising and Society Review, Vol. 8 No. 2.

Hunt, R. (2018). "The pope says God made gay people just as we should be - here's why his comments matter". The Guardian, available at:

https://www.theguardian.com/world/shortcuts/2018/may/21/the-pope-says-god-made-gaypeople-just-as-we-should-be-heres-why-his-comments-matter (accessed 14 May 2019).

Ivory, A.H. (2019). "Sexual Orientation as a Peripheral Cue in Advertising: Effects of Model's Sexual Orientation, Argument Strength and Involvement on Responses to Magazine Ads". Journal of Homosexuality. Vol. 66 No. 1, pp. 31-59. 
Kates, S.M. (1999). "Making the ad perfectly queer: Marketing 'normality' to the gay mens' community". Journal of Advertising, Vol. 28 No. 1, pp. 25-37.

Kakkuri-Knuuttila, M.L., Lukka, K. and Kuorikoski, J. (2008). "Straddling between paradigms: A naturalistic philosophical case study on interpretive research in management accounting". Accounting, Organisations and Society. Vol. 33 No. 2-3, pp. $267-291$.

Kane, E.W., (2006). “No way my boys are going to be like that!" Parents' responses to children's gender nonconformity. Gender \& Society, Vol. 20 No. 2, pp.149-176.

Kitzinger, C. (2001). "Sexualities". In RK Unger (Ed.), Handbook of the psychology of women and gender (pp. 272-285), John Wiley \& Sons Inc.

Knauer, N.J. (2007). "Gender Matters: Making the Case for Trans Inclusion". Pierce Law Review, Vol. 6 No. 1, pp. 1-12.

Langford, J. and McDonagh, D. (2003). "Focus groups: Supporting effective production development". London: Taylor and Francis.

Levinson-King R. (2018). "Children's toys: The backlash against pink and blue branding". BBC News, available at: https://www.bbc.co.uk/news/world-us-canada-46613032 (accessed 21 March 2019).

Levi, J. (2006). "Clothes Don't Make the Man (or Woman), But Gender Identity Might". Sexuality and the Law Commons. 15 Colum, available at:

https://digitalcommons.law.wne.edu/cgi/viewcontent.cgi?article=1025\&context=facschol (accessed 9 May 2019).

Lewis, P., Benschop, Y. and Simpson, R. (2017). "Postfeminism, Gender and Organization". Gender, Work and Organization, Vol. 24 No. 3, pp. 213-225.

Lombardi, E.L., Wilchins, R.A., Priesing, D. and Malouf, D. (2002). "Gender violence: Transgender experiences with violence and discrimination". Journal of Homosexuality, Vol. 42 No. 1, pp. 89-101.

Lui, R.L. and Minton, E.A. (2018). "Faith-filled brands: The interplay of religious branding and brand engagement in the self-concept". Journal of Retailing and Consumer Services. Vol No. 0, pp. 44: 305314.

McCracken, G. (1990). "Culture and Consumption: New Approaches to the Symbolic Character of Consumer Goods and Activities". Bloomington and Indianapolis: Indiana University Press.

McIntyre, J. (2018). "They're So Normal I Can't Sand It': I Am Jazz, I Am Cait”, Transnormativity and Transfeminism, Orienting Feminism 1(1): 9-24.

McPhail, B.A. and DiNitto, D.M., (2005). "Prosecutorial perspectives on gender-bias hate crimes. Violence Against Women", Vol. 11 No, 9, pp.1162-1185. 
Nölke, A.I. (2018). "Making Diversity Conform? An Intersectional, Longitudinal Analysis of LGBTSpecific Mainstream Media Advertisement". Journal of Homosexuality, Vol. 65 No. 2, pp. 224-255.

Oakenfull, G.K. and Greenlee, T.B. (2005). "Queer eye for a gay guy: Using market-specific symbols in advertising to attract gay consumers without alienating the mainstream". Psychology \& Marketing, Vol. 22 No. 5, pp. 421-439.

Peters, C., Shelton, A. and Thomas, B. (2011). "Self-concept and the fashion behavior of women over 50". Journal of Fashion Marketing and Management: An International Journal, Vol. 15, pp. 291-305.

Pounders, K. and Mabry-Flynn, A. (2016). "Consumer response to gay and lesbian imagery: how product type and stereotypes affect consumers' perceptions". Journal of Advertising Research, Vol. 56 No. 4, pp. 426-440.

Preziosi, D., (2009). Art, land, and the gendering of Parnassus. Semiotica, 2009 (175), pp.177-191.

Quach, S., Jebarajakirthy, C. and Thaichon, P. (2017). "Aesthetic labor and visible diversity: The role in retailing service encounters". Journal of Retailing and Consumer Services Vol. 38 No. 0, pp. 34-43

Ritch, E.L. and Brownlie, D. (2016). "Everyday dramas of conscience: Navigating identity through creative neutralisation". Journal of Marketing Management. Vol. 32 No. 9/10, pp. 1012-1032.

Rosenbaum, M.S., Russell, E.M., and Russell-Bennett, R. (2017). ““'Ill wait for him”: Understanding when female shoppers prefer working with gay male sales associates". Journal of Retailing and Consumer Services Vol. 36. No. 0, pp. 172-179.

Rosenbaum, M.S., Russell-Bennett, R. and Drennan, J. (2015). “Commercial friendships between gay sales associates and straight female customers in luxury settings: A proposed theoretical framework". Journal of Retailing and Consumer Services Vol. 27 No. 0, pp. 179-186.

Rysst, M., (2010). "'I Am Only Ten Years Old' Femininities, clothing-fashion codes and the intergenerational gap of interpretation of young girls' clothes". Childhood, Vol. 17 No. 1, pp.76-93.

Saner, E. (2017). "Joy of unisex: the rise of gender-neutral clothing". The Guardian, available at: https://www.theguardian.com/lifeandstyle/2017/sep/04/joy-unisex-gender-neutral-clothing-johnlewis (accessed 22 March 2019).

Sender, J., (1999). "Africa's economic performance: limitations of the current consensus. Journal of Economic Perspectives", Vol. 13 No. 3, pp.89-114.

Sender, K. and Shaw, A. eds., (2017). "Queer Technologies: Affordances, Affect, Ambivalence". Taylor \& Francis.

Schofield, K. and Schmidt, R.A. (2005). "Fashion and clothing: the construction and communication of gay identities". International Journal of Retail \& Distribution Management, Vol. 33 No. 4, pp. 320-323. 
Schroeder, J.E. and Zwick, D. (2004). "Mirrors of Masculinity: Representation and Identity in Advertising Images". Consumption Markets and Culture, Vol. 7 No. 1, pp. 21-52.

Sha, O., Ang, M.L., Ondervilee, J. and Ralston, C.E. (2007). “Understanding gay consumers' clothing involvement and fashion consciousness". International Journal of Consumer Studies Vol. 31, pp. 453459.

Smithson, J. (2000). "Using and analysing focus groups: Limitations and possibilities". International Journal of Social Research Methodology, Vol. 3 No.2, pp. 103-119.

Snyder, B. (2015). "LGBT advertising: How brands are taking a stance on issues". Think with Google, available from: https://www.thinkwithgoogle.com/intl/en-gb/consumer-insights/lgbt-advertisinghow-brands-are-taking-stance-issues/ (accessed 17 January 2020).

Stewart, K. and Cole, M. (2019). "Meat is masculine: how food advertising perpetuates harmful gender stereotypes". The Conversation, available from: https://theconversation.com/meat-is-masculinehow-food-advertising-perpetuates-harmful-gender-stereotypes-119004 (accessed 28 May 2020)

Stotzer, R.L., (2009). "Violence against transgender people: A review of United States data". Aggression and Violent Behavior, Vol. 14 No. 3, pp.170-179.

Tajfel, H. (1982). "Social psychology of intergroup relations", Annual Review of Psychology, Vol. 33, pp. 1-39.

Takács, J. (2006). "Social exclusion of young lesbian, gay, bisexual and transgender (LGBT) people in Europe". Brussels, Belgium: ILGA Europe.

Testa, R.J., Sciacca, L.M., Wang, F., Hendricks, M.L., Goldblum, P., Bradford, J. and Bongar, B. (2012). "Effects of violence on transgender people". Professional Psychology: Research and Practice, Vol. 43 No. 5, pp. 452.

Tsai, W.S. (2012). "Political issues in advertising polysemy: the case of gay window advertising". Consumption Markets and Culture, Vol. 15 No. 1, pp. 41-62.

Turner, J.C. (1985). "Social categorisation and the self-concept: A social cognitive theory of group behaviour". E.J. Lawler Advances in group processes: theory and research Greenwich, CT: JAI. Vol. 2, pp. 22-122.

Turner, J.C. (1999). "Some current issues in research on social identity and self-categorization theories". Ellemers, N., Spears, R. and Doosje, B. Social identity: Context, Commitment, Oxford: Blackwell. pp. 6-34.

Turner, J.C., Hogg, M.A., Oakes, P.J., Reicher, S.D. and Wetherell, M.S. (1987). "Rediscovering the social group: a Self-categorization Theory". Oxford: Blackwell 
Um, N-H. (2016). "Consumers' response to Implicit and Explicit Gay-Themed Advertising in Gay vs. Mainstream Media". Journal of Promotion Management, Vol. 22 No. 3, pp. 461-477.

Woo, A. (2018). "The Forgotten Generation: Let's Talk About Generation X". Forbes, available from: https://www.forbes.com/sites/forbesagencycouncil/2018/11/14/the-forgotten-generation-lets-talkabout-generation-x/\#53025e5276d5 (accessed 30 November 2019)

Woodruffe-Burton, H. (1998), "Private desires, public display: consumption, postmodernism and fashion's 'new man'”, International Journal of Retail and Distribution Management, Vol. 26 No. 8, pp. 301-10.

Yin, R.K., (2003). "Case study research: design and methods" (ed.). Thousand Oaks. 


\section{Response to the reviewers May2020}

\section{Reviewer 1}

\begin{tabular}{|c|c|c|}
\hline & Comment & Response \\
\hline $1 a$ & $\begin{array}{l}\text { please take a look at the format and organization of articles published by } \\
\text { International Journal of retail and Distribution Management. Your paper in its } \\
\text { current form does not fit into the format in terms of parts and titles. Your titles } \\
\text { are neutral and descriptive, they should help the reader move ahead in your } \\
\text { arguments. }\end{array}$ & $\begin{array}{l}\text { We have changed the title to reflect output value better. } \\
\text { We have changed sub-headings to reflect section value better. }\end{array}$ \\
\hline $1 b$ & $\begin{array}{l}\text { Introduction : your research objective does not currently comes across. it } \\
\text { seems that you want to address the difficulty of managing diversity in terms of } \\
\text { image for retailers? If so, you have to tell us why this "diverse" clientèle is } \\
\text { interesting for retailers (generational shifts that bring younger and more open- } \\
\text { minded consumers to retailers, but difficulty of managing senior and younger } \\
\text { customers' expectations ...) : please include numbers. For example, look at this } \\
: \text { https://observatoirecetelem.com/wp-content/themes/obs-cetelem- } \\
\text { v3/publications/2018/observatoire-cetelem-consommation-2018.pdf }\end{array}$ & $\begin{array}{l}\text { We have clarified the purpose of the work with clear statements of aim and objectives in the } \\
\text { introduction (final paragraph) and a revised abstract statement: } \\
\text { 'the aim of this exploratory research is to examine the perceptions of mainstream UK } \\
\text { consumers towards sexuo-gendered identities, as represented within retail marketing } \\
\text { communications. The objective of the paper is to explore the value of developing more } \\
\text { progressive, inclusive brand values to support effective, retail brand communications.' } \\
\text { The reviewer is correct in suggesting that part of our position is that generational shifts will } \\
\text { bring strategic caveats into focus for retailers and we seek to clarify this within the work: } \\
\text { '...evident, differential priorities of different identity groups and the value of this knowledge to } \\
\text { informing retail brand value creation, strategy and practice.' } \\
\text { We have also added a section that discusses age and its moderating role within sexuo-gendered } \\
\text { understandings - within the section 'mapping social identities to markets...' }\end{array}$ \\
\hline 1c & $\begin{array}{l}\text { Please tell us at the end of your introduction how you are going to address the } \\
\text { issue of retailers brands and "diversity". } \\
\text { Please include some definitions, historical perspectives on the development of } \\
\text { categories such as LGBTQIA+ or "sexuo gendered". }\end{array}$ & $\begin{array}{l}\text { Thanks for pointing out that this needs more clarity. } \\
\text { In terms of offering a historical perspective and definition, the following sentence was added to } \\
\text { page 2" } \\
\text { Over the last decade, what was termed the gay community has expanded beyond LGB to } \\
\text { LGBTQIA+, to those questioning (Q) their gender and sexuality, transsexuals, intersex and } \\
\text { asexual with the plus illustrating the multiple other sexual and gender identities (see Gold, } 2019 \\
\text { for a full explanation of the terminology covering the gender and sexuality spectrum). } \\
\text { On page 3, there is a sentence on how LGBTQIA+ diversity will be researched: } \\
\text { Therefore, this research will utilise photoelicitation to explore consumer perceptions of } \\
\text { LGBTQIA+ imagery which has been used in marketing to better understand how this informs } \\
\text { constructs of retail brand value. }\end{array}$ \\
\hline
\end{tabular}




\begin{tabular}{|c|c|c|}
\hline & & $\begin{array}{l}\text { Also on page } 3 \text { the research aim and objective are established: } \\
\text { Consequently, the aim of this exploratory research is to examine the perceptions of } \\
\text { mainstream UK consumers towards sexuo-gendered identities, as represented within retail } \\
\text { marketing communications. The objective of the paper is to explore the value of developing } \\
\text { more progressive, inclusive brand values to support effective, retail brand communications. }\end{array}$ \\
\hline $1 d$ & What is the impact of digital spaces on these categories? & $\begin{array}{l}\text { Thank you for questioning the use of digital space. This was not part of our investigation, nor } \\
\text { was it addressed in the literature sourced for developing the literature review - despite the } \\
\text { online retail sector being established when the literature was published. Data collection } \\
\text { focused upon investigating perceptions of diverse sexual and gendered identities of retail brand } \\
\text { value constructs, from imagery that can be found online and through other marketing channels. } \\
\text { We could find literature that suggests retailers have a consistent message throughout all } \\
\text { marketing channels, but this would be taking the aim and objective of the paper in another } \\
\text { direction. Further, we could address niche LGBTQIA+ retailers, who are perhaps accessible } \\
\text { through digital spaces, but this does not align with our argument that diversity should be more } \\
\text { reflected in mainstream markets. }\end{array}$ \\
\hline $1 \mathrm{e}$ & $\begin{array}{l}\text { In the results part, please focus on retail and on the issues that retailers have } \\
\text { to cope with with regards to these issues. }\end{array}$ & $\begin{array}{l}\text { Thank you. Noted throughout the discussion are recommendations for retail marketers to } \\
\text { respond to these issues, particularly with regard to the mainstream inclusion of sexuo- } \\
\text { gendered images in brand advertising. }\end{array}$ \\
\hline $1 \mathrm{f}$ & $\begin{array}{l}\text { At some point, you also have to explain where you are speaking from : are you } \\
\text { based in Europe? in which country? You are addressing these issues from that } \\
\text { point of view, which might be different then the point of view of a researcher } \\
\text { based in Australia or in Spain. }\end{array}$ & $\begin{array}{l}\text { We note in the abstract and the methods that this is a sample drawn from a UK population. We } \\
\text { also seek to make clearer that this is UK based in response to an over-representation of US- } \\
\text { centric studies on this broader area. }\end{array}$ \\
\hline $1 \mathrm{~g}$ & $\begin{array}{l}\text { Literature review : please open to feminist and post feminist literature as well } \\
\text { as the one on body positivism. } \\
\text { The paper demonstrate in some respect an adequate understanding of the } \\
\text { literature on the different issues related to "diversity" or "inclusivity". But large } \\
\text { areas of the feminist, post feminism literature is not mobilized (De Beauvoir? } \\
\text { Butler? Kristeva? Delphy???). }\end{array}$ & $\begin{array}{l}\text { While we acknowledge that there is a vast amount of interesting work on feminism, post- } \\
\text { feminism and body positivism, this was not the aim of the research - the aim was on diverse } \\
\text { identity construction. Specifically, the research was designed by a gay male, with a focus on the } \\
\text { diversity of gay and lesbian representations. What emerged organically was the perceptions of } \\
\text { the two female cohorts that there were still patriarchal messages that insinuate 'sex sells' in } \\
\text { marketing, which is replicated in lesbian and gay imagery also. While we acknowledge that this } \\
\text { falls under the remit of feminism, post feminism and body positive movements, as this is not } \\
\text { the focus of this research it is not included. However, it is a research agenda that we aim to } \\
\text { take forward with the collection of more data to cover those themes. }\end{array}$ \\
\hline $1 \mathrm{~h}$ & $\begin{array}{l}\text { Additionally, no precise definitions or historical perspectives are given to the } \\
\text { different terms of "gender", "sexuo-gender", LGBTQIA+... How have these } \\
\text { categories emerged in the literature? In which literature? }\end{array}$ & $\begin{array}{l}\text { We agree that this can seem confusing and thank you for requesting this is addressed. } \\
\text { Historical advances of the LGBTQIA+ and the terminology expansion are included on page } 2 \text {. } \\
\text { On page } 1 \text { there is an explanation of how we coined the term sexuo-gender: } \\
\text { These 'sexuo-gendered' identities (covering multiple sexual and gender representations), } \\
\text { where gender and sexuality fuse within a more inclusive and progressive understanding, may } \\
\text { offer a useful base from which to explore relationships between people and retail brands. }\end{array}$ \\
\hline
\end{tabular}




\begin{tabular}{|c|c|c|}
\hline & & $\begin{array}{l}\text { These categories have emerged from Gong (2019) and Nölke (2018) commenting that minority } \\
\text { sexuo-gendered identities are not represented in mainstream media representations (see page } \\
\text { 5): } \\
\text { Yet, Nölke (2018) questioned the value of using sexual orientation for target marketing, } \\
\text { because much of the advertisers' understanding may be constructed within stereotypical } \\
\text { assumptions that exclude the spectrum of sexuo-gendered identities. Gong (2019) and Nölke } \\
\text { (2018) posited that minority sexuo-gendered identities, such as genderqueer, 'femme' males, } \\
\text { 'butch' lesbians, bisexuals and transsexuals are invisible in media representations. }\end{array}$ \\
\hline $1 \mathrm{i}$ & $\begin{array}{l}\text { Are these categories only western categories? When and how have they } \\
\text { emerged in the marketing and retail literature? Please give us some } \\
\text { perspectives. It might be usefull to tie your topic to body positivism and the } \\
\text { work of Alexandra Sastre. Could the socialisation theory be rediscovered } \\
\text { through the lens of your work in a more innovative way? }\end{array}$ & $\begin{array}{l}\text { Thank you for highlighting this. Although not purely western categories, research on LGBTQIA+ } \\
\text { issues in non-western societies has tended to be in the area of sociology and gender identity } \\
\text { (Berry, et al., 2003). Literature on gender identities in marketing emerged in the mid 1990s, } \\
\text { however, there are few studies in the area of retail marketing (p2) }\end{array}$ \\
\hline $1 \mathrm{j}$ & $\begin{array}{l}\text { Methodology : be more explicit in terms of construction of focus groups and } \\
\text { choice of images. }\end{array}$ & $\begin{array}{l}\text { We agree that by establishing the criteria and rationale for selecting the imagery will help to } \\
\text { contextualise the data and offer more validity. Added to age 9: } \\
\text { The imagery was selected as it was used by brands to support Pride (the annual celebration of } \\
\text { sexual and gender diversity) or to illustrate progressive brand value (Ivory, 2019; Grau and } \\
\text { Zotos, 2016). Therefore, the imagery challenges perceptions of in-group and out-group } \\
\text { identities, especially as the images present more explicit content, such as intimacy between } \\
\text { same gender/transgender models (Dotson et al., 2009). As two of the images include } \\
\text { transgender models, typically underrepresented in mainstream communications, the research } \\
\text { seeks to update Testa et al.'s (2012) assumption that the transgender cohort are still } \\
\text { unaccepted, as well as provide insight into what is considered explicit or challenging lifestyles. } \\
\text { All of the imagery emerged from well-established international retail brands. Although Play Boy } \\
\text { is primarily an American men's lifestyle and entertainment magazine, there are associated } \\
\text { commodities sold with the brand logo that represents a particular lens of gender and sexuality } \\
\text { - therefore the inclusion of a transgender model challenges hyper-masculinity. }\end{array}$ \\
\hline $1 \mathrm{k}$ & $\begin{array}{l}\text { The methodology is very interesting with different focus groups with male and } \\
\text { female informants. Nevertheless, one can question the notion of generations } \\
\text { (why does it appear in the methodology and not more clearly in the literature } \\
\text { review? what are your hypothesis with regards to generations?), the } \\
\text { composition of the focus groups dedicated to women (why no homosexual } \\
\text { women?). }\end{array}$ & $\begin{array}{l}\text { See } 1 b \text { for the hypothesis on focus group selection } \\
\text { Agree that Smithson's generational insight should be introduced in the literature review and so } \\
\text { we have inserted the sentence below on page } 7 \text { : } \\
\text { This could also be reflected in assuming that younger cohorts are more tolerant of diverse } \\
\text { sexuo-gender (Smithson, 2000). } \\
\text { Sexuality was not a criterion for participating in a focus group, this is reflected in the following } \\
\text { sentence on page 8: }\end{array}$ \\
\hline
\end{tabular}


Other questions that need to be adressed : how did you choose the images, according to which criterias? what is the relationship to the question of retail?

$1 \mathrm{~m} \quad$ Results are currently too descriptive because they are not related to a clear question in relation to retail.

1n $\quad$ Results are interesting but currently are not well presented or organized. The issue of religion for example comes up which should be addressed earlier in more extent.

$10 \quad$ The second difficulty is that results are related to "marketing" in general and

1p Nevertheless and despite these difficulties, your contribution is very relevant and interesting.

1q $\quad$ The theme of the paper must be addressed by retail marketers, but in its actual form, it does not provide clear management recommandations. The issue of better representing "diversity" in its different forms has to be addressed by marketers, in order to better answer society needs and evolutions. I think it could make a very valuable contribution by going back to concepts and categories and addressing these in the context of retail.

1r $\quad$ The paper is well written but not well structured and problematised. It is difficult to follow the reasonning and how it ties into retail issues in a constructive way. The author uses a lot of references (some of them are too frequently mentioned) but does not help the reader to go from one point to the next. By going back to basic notions and categories, your paper, that addresses important issues for retailers and society, will gain in quality and readability. do not clearly address "retail" issues.

Sexuality was not a prescribed criterion but was recorded (with permission) and, subsequently, was used to further differentiate focus groupings.

As above, in $1 \mathrm{j}$ for explanation of image selection and criteria as well as relationship to retail.

We have tried to clarify this throughout and have tailored the aims of the work to include the retail focus (retail brand creation)

We tried to formalise the discussion of data. Namely, 4 sections are identified within the discussion and these emanate from the literature review. Also, each of the four sections has dedicated discussion of its relevance to a social identity framework

We've tried to be clearer about the place of retailing within the work

Thank you for your positive comments, we too have found the research interesting :;

Thank you. P17 and 18 postulates the need for marketing and retail marketing to represent a wider inclusive spectrum of identity to indicate progressive brand values, particularly younger consumers who feel misrepresented by dualistic binaries

We have amended the paper to further emphasise throughout and in particular in the setup of the paper, the value to retailers and retail marketing more general. Some areas also show relevance to wider marketing value and societal value. The work is structured more clearly (we hope) to show how the problem stated within the objective is operationalised and explored within the work.

\section{Reviewer 2}

\begin{tabular}{l|}
34 \\
36 \\
9 \\
4 \\
4 \\
4 \\
4 \\
4
\end{tabular}

We have tried to clarify the rationale for the research within the introduction and hope this ma facilitate faster appreciation within the wider readership.

Thank you for clarifying that the premise of the argument is clear and would contribute as a basis for further research. We also feel that the findings are novel and capture change in societal perceptions. "paper argues that a move towards full inclusion for all sexuo-gendered identities within societal discourse offers the opportunity for brand values to play a positive role in 


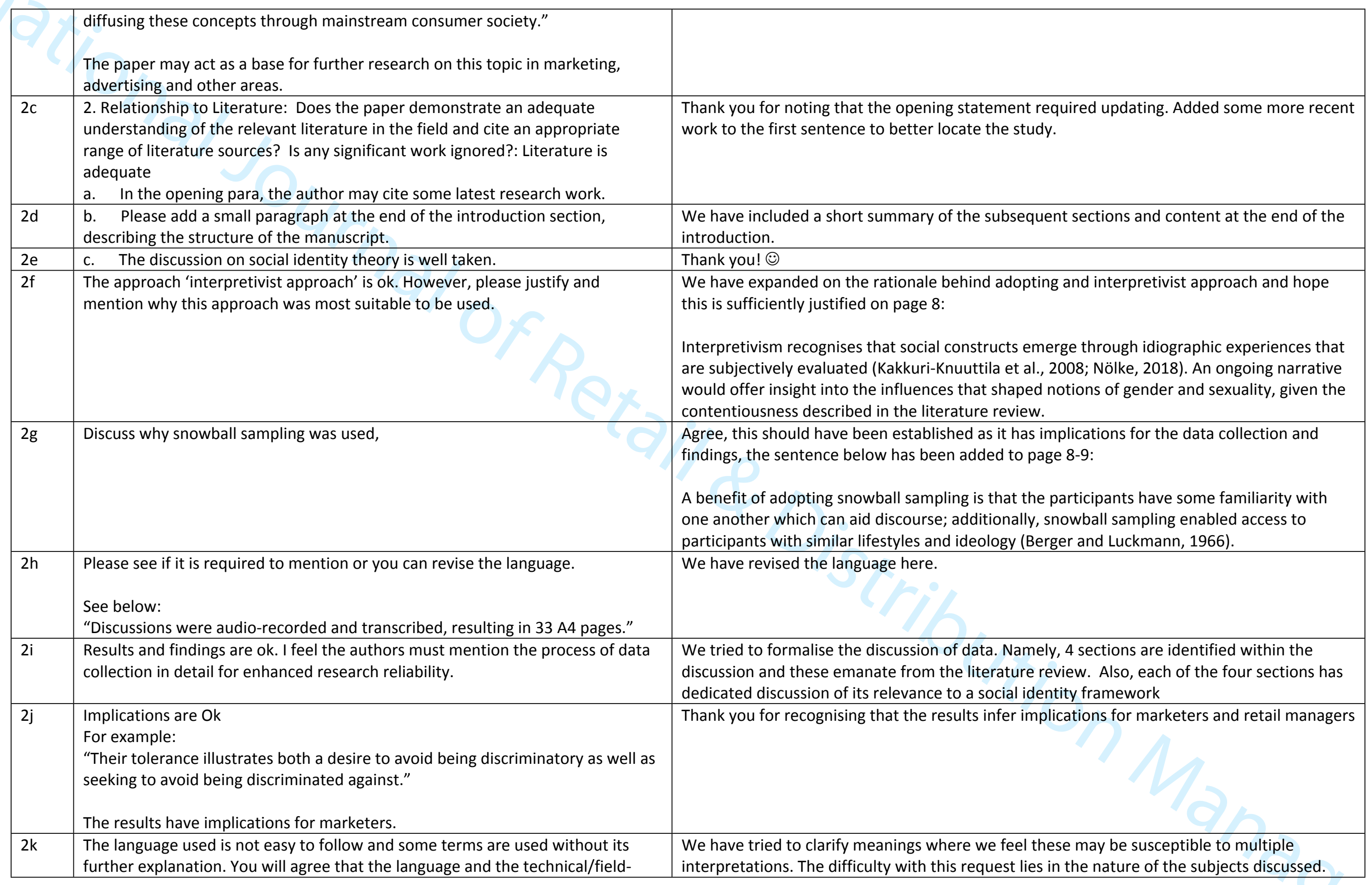


specific terms must be used by keeping the average-readers into consideration.

Hence, this paper is not having the ease of reading.

Moreover, the abstract can be revised for more clarity coupled with simplistic

language.
These tend to have prescribed terminology (at least by convention) and, by modifying the terminology, we risk losing the accepted meaning. We hope that our changes will suffice. We have sought to clarify and simplify the abstract. 


\section{Table 1: Images used to stimulate discussion}

\begin{tabular}{|c|c|c|c|c|}
\hline Brand & Year & Campaign & Description of imagery & Purpose \\
\hline $\begin{array}{l}\text { American } \\
\text { Apparel }\end{array}$ & 2012 & $\begin{array}{l}\text { In launching a line of } \\
\text { LGBT clothing in } \\
\text { celebration of Pride } \\
\text { month, } 2 \text { marketing } \\
\text { images were created: } 1 \\
\text { featured a female } \\
\text { couple and } 1 \text { featured a } \\
\text { male couple. }\end{array}$ & $\begin{array}{l}\text { 1. Female couple kissing on the } \\
\text { lips with their arms wrapped } \\
\text { round each other, one } \\
\text { wearing a dress and the } \\
\text { other wearing a pinafore } \\
\text { with no top underneath and } \\
\text { the side of her breasts visible } \\
\text { - this is a sexualised image } \\
\text { 2. Male couple kissing on the } \\
\text { lips with their arms wrapped } \\
\text { round each other, both } \\
\text { wearing a t-shirt that } \\
\text { supports LGBT pride - less } \\
\text { sexualised image } \\
\text { In both images, the models are } \\
\text { attractive, slim and white. }\end{array}$ & Marketing \\
\hline $\begin{array}{l}\text { Calvin } \\
\text { Klein }\end{array}$ & 2015 & $\begin{array}{l}\text { The advertisement } \\
\text { features a gay couple for } \\
\text { the first time to } \\
\text { advertise the jeans } \\
\text { range. }\end{array}$ & $\begin{array}{l}\text { Two males facing each other as } \\
\text { though about to kiss, this is a tender } \\
\text { image. Both models are attractive, } \\
\text { well-groomed and white. }\end{array}$ & Marketing \\
\hline $\begin{array}{l}\text { Jean Paul } \\
\text { Gaultier }\end{array}$ & 2011 & $\begin{array}{l}\text { SS11 featuring } \\
\text { transgender model } \\
\text { Andrej Pejic. }\end{array}$ & $\begin{array}{l}\text { Female and trans male to female } \\
\text { couple, facing forward with one arm } \\
\text { around each other and their legs } \\
\text { entwined. Their faces are very close, } \\
\text { mouths parted as though about to } \\
\text { kiss. As expected in a fashion } \\
\text { advertisement, this is very stylised } \\
\text { and the models are thin, aesthetically } \\
\text { pleasing and white. }\end{array}$ & Marketing \\
\hline GAP & 2012 & $\begin{array}{l}\text { Public endorsement for } \\
\text { the LGBT community }\end{array}$ & $\begin{array}{l}\text { Male couple, facing forward and } \\
\text { looking directly at the camera. Both } \\
\text { heads are in the neck of one t-shirt, } \\
\text { and the advert has the tag line 'Be } \\
\text { One'. Both models are attractive and } \\
\text { white. }\end{array}$ & $\begin{array}{c}\text { Social } \\
\text { Marketing }\end{array}$ \\
\hline Playboy & 2017 & $\begin{array}{l}\text { Playboy feature their } \\
\text { first ever transgender } \\
\text { playmate, Ines Rau, in } \\
\text { the } \\
\text { November/December } \\
2017 \text { issue. }\end{array}$ & $\begin{array}{l}\text { The transgender model is lying on } \\
\text { her front wearing a white bra and a } \\
\text { g-string with white socks and } \\
\text { trainers. She is well-groomed, toned, } \\
\text { tanned and looking directly at the } \\
\text { camera. }\end{array}$ & Entertainment \\
\hline
\end{tabular}


